\title{
PENGARUH DUKUNGAN SUPERVISOR DAN PEMBERDAYAAN TERHADAP ORGANIZATIONAL CITIZENSHIP BEHAVIOR
}

\author{
Tinjung Desy Nursanti; Aida Dwi Anissa \\ Management Department, School of Business Management, BINUS University \\ Jln. K.H. Syahdan No. 9, Palmerah, Jakarta Barat 11480 \\ tinjungdesy@yahoo.com; aida.anissa@yahoo.com
}

\begin{abstract}
Study aims to determine and obtain a clear picture of supportive supervisor, empowerment, and organizational citizenship behavior; and to determine the impact of supportive supervisor and empowerment towards organizational citizenship behavior of employees in PT Setia Makmur Cemerlang. Research used explanatory survey method, while the sample was taken from employees of the company. Research instrument (questionnaires) was used as primary data collection to explain the causal relationship between supportive supervisor and empowerment on organizational citizenship behavior of employees in PT Setia Makmur Cemerlang. Analysis used simple linear regression and multiple linear regression method. Result of this study shows that there is significant influence between supportive supervisor and empowerment towards organizational citizenship behavior.
\end{abstract}

Keywords: supportive supervisor, empowerment, organizational citizenship behavior

\begin{abstract}
ABSTRAK
Penelitian bertujuan untuk mengetahui dan memperoleh gambaran yang jelas tentang dukungan supervisor, pemberdayaan, dan organizational citizenship behavior. Penelitian juga bertujuan untuk menentukan dampak dari dukungan supervisor dan pemberdayaan terhadap organizational citizenship behavior karyawan PT Setia Makmur Cemerlang. Penelitian menggunakan metode survei eksplanatori; sampel diambil dari setiap karyawan di perusahaan. Instrumen penelitian (kuesioner) dipakai sebagai data primer untuk menjelaskan hubungan sebab-akibat antara dukungan supervisor dan pemberdayaan terhadap organizational citizenship behavior karyawan PT Setia Makmur Cemerlang. Metode analisis yang digunakan adalah regresi linier sederhana dan regresi linier berganda. Hasil penelitian menunjukkan bahwa ada pengaruh signifikan antara dukungan supervisor dan pemberdayaan terhadap organizational citizenship behavior.
\end{abstract}

Kata kunci: dukungan supervisor, pemberdayaan, organizational citizenship behavior 


\section{PENDAHULUAN}

Industri telekomunikasi dalam lima tahun belakangan ini sedang mengalami pertumbuhan yang sangat pesat dan menjadi salah satu sektor yang makin menjanjikan bagi perkembangan perekonomian serta teknologi di Indonesia. Hal ini makin mendorong pemerintah Indonesia berupaya meningkatkan investasi asing pada sektor tersebut baik melalui dukungan perbankan nasional maupun internasional. Tuntutan masyarakat terhadap kebutuhan pemenuhan layanan di bidang telekomunikasi berkembang sangat cepat seiring dengan kemajuan perekonomian negara. Untuk memenuhi kebutuhan tersebut, para operator telekomunikasi saling berlomba untuk segera membangun menara transmisi sebagai salah satu kelengkapan infrastruktur dalam menunjang kelancaran telekomunikasi. Bisnis di bidang ini dirasa masih menjanjikan dan dapat memenuhi kebutuhan pasar secara luas. PT Setia Makmur Cemerlang (SMC) yang berdiri pada 2000 adalah perusahaan yang bergerak di bidang pembangunan dan jasa konstruksi menara telekomunikasi.

Dalam menghadapi persaingan yang makin ketat serta dihadapkan pada kondisi pasar bebas yang makin mendominasi, pada akhirnya hanya perusahaan-perusahaan dengan keunggulan kompetitif saja yang dapat tetap eksis. Situasi tersebut menyadarkan perusahaan untuk memiliki tujuan strategis terbaik dalam rangka mencapai keunggulan, baik keunggulan untuk tetap survive maupun untuk bersaing dengan organisasi lain. Perusahaan yang ingin mencapai keunggulan tersebut harus meningkatkan kinerja individu karyawannya karena pada dasarnya kinerja individu memengaruhi kinerja tim atau kelompok kerja yang pada akhirnya memengaruhi kinerja perusahaan secara menyeluruh.

Untuk mencapai kinerja yang baik, karyawan dituntut untuk menunjukkan perilaku yang sesuai dengan perusahaan. Pada evaluasi kinerja pegawai para manajer biasanya tidak hanya menilai perilaku formal saja, misalnya dengan datang tepat waktu atau mengerjakan tugas yang diperintahkan atasan. Lebih lanjut, manajer juga mengobservasi dan ikut menilai perilaku informal yang diperlihatkan karyawan itu sendiri, misalnya dengan sukarela membantu karyawan lain untuk menyelesaikan tugas atau menjalin hubungan baik dengan semua karyawan dengan tidak membicarakan keburukan karyawan lain. Perilaku informal pada karyawan seperti dipaparkan sebelumnya adalah perilaku yang sangat dihargai di perusahaan, karena hal tersebut dapat meningkatkan efektivitas dan kesuksesan perusahaan. Perilaku informal tersebut disebut sebagai organizational citizenship behavior (OCB).

Organizational citizenship behavior (OCB) dapat dipengaruhi oleh dukungan supervisor dan pemberdayaan. Dukungan supervisor dan pemberdayaan sangat penting bagi semua organisasi yang menerapkan konsep OCB. Supervisor adalah orang yang terlibat langsung dalam konteks pekerjaan individu, karena dukungan supervisor memiliki pengaruh langsung terhadap perilaku bawahan. Dukungan supervisor dapat membantu menciptakan lingkungan tempat karyawan dengan mudah terlibat dalam organizational citizenship behavior (Kozlowki \& Doherty dalam Zaigham, 2010). Adapun pengertian pemberdayaan adalah suatu proses yang membebaskan kekuatan dalam diri karyawan untuk meraih hasil yang baik (Ken, John, \& Alan, 2013). Pemberdayaan karyawan sangat diperlukan perusahaan untuk dapat bersaing di dunia bisnis saat ini dan tentunya pada masa yang akan datang. Lebih banyak karyawan dapat terlibat dalam organizational citizenship behavior (OCB), maka hal tersebut akan membuat organisasi menjadi lebih sukses.

Hasil penelitian Zaigham (2010) menunjukkan bahwa dukungan supervisor dan pemberdayaan memiliki hubungan positif dengan organizational citizenship behavior. Di samping itu, organisasi harus merancang kebijakan yang lebih baik untuk mempromosikan OCB. Adapun hasil penelitian Jin-Liang dan Hai-Zhen (2012) menjelaskan bahwa pemberdayaan psikologis memiliki pengaruh yang signifikan terhadap kepuasan kerja karyawan dan OCB. Pemberdayaan psikologis pada 
OCB dimediasi oleh kepuasan kerja. Terdapat variabel moderating yaitu dukungan supervisor sebagai faktor yang memperkuat dan memperlemah hubungan antara pemberdayaan psikologis dengan OCB.

Pada dasarnya, suatu perusahaan tentu tidak akan berjalan tanpa sumber daya manusia (SDM) andal yang menanganinya. Tanpa kemampuan yang baik dari karyawan, tujuan yang ditetapkan perusahaan tidak akan pernah tercapai. Berdasarkan uraian, penelitian ini dilakukan yang bertujuan untuk mengetahui pengaruh dukungan supervisor dan pemberdayaan terhadap organizational citizenship behavior (OCB) pada PT Setia Makmur Cemerlang (SMC). Pertanyaan-pertanyaan yang muncul dan akan dijawab dalam penelitian ini adalah: (1) Apakah dukungan supervisor berpengaruh terhadap organizational citizenship behavior (OCB); (2) Apakah pemberdayaan berpengaruh terhadap organizational citizenship behavior (OCB); dan (3) Apakah dukungan supervisor dan pemberdayaan berpengaruh terhadap organizational citizenship behavior (OCB).

Tujuan dari penelitian ini adalah untuk mengetahui dan memperoleh gambaran yang lebih jelas mengenai dukungan supervisor dan pemberdayaan pada PT Setia Makmur Cemerlang (SMC) terhadap organizational citizenship behavior (OCB). Berdasarkan rumusan masalah tersebut diharapkan perusahaan akan mengetahui hal-hal berikut: (1) seberapa besar pengaruh dukungan supervisor dalam perusahaan terhadap organizational citizenship behavior (OCB); (2) seberapa besar pengaruh pemberdayaan dalam perusahaan terhadap organizational citizenship behavior (OCB); (3) seberapa besar pengaruh dukungan supervisordan pemberdayaan PT Setia Makmur Cemerlang (SMC) terhadap organizational citizenship behavior (OCB).

\section{METODE}

Penelitian menggunakan metode survei. Survei digunakan untuk mendapatkan data dari tempat tertentu yang alamiah (bukan buatan) dengan pengumpulan data, misalnya dengan mengedarkan kuesioner, tes, wawancara terstruktur, dan sebagainya (Sugiyono, 2009). Jenis penelitian yang digunakan adalah penelitian asosiatif. Penelitian asosiatif merupakan penelitian yang bertujuan untuk mengetahui hubungan antara dua variabel atau lebih. Dalam hal ini, penelitian difokuskan pada dukungan supervisor dan pemberdayaan terhadap organizational citizenship behavior (OCB) karyawan PT Setia Makmur Cemerlang (SMC). Kemudian data tersebut ditabulasi, diolah, dan dianalisis untuk menjelaskan pengaruh dukungan supervisor dan pemberdayaan terhadap OCB. Unit analisis dalam penelitian ini adalah individu dengan time horizon bersifat cross section karena informasi yang dikumpulkan hanya sekali dengan tujuan untuk mendapatkan jawaban atas pertanyaan penelitian (Sekaran \& Roger, 2010). Adapun jenis data yang digunakan dalam penelitian ini adalah data kuantitatif, yaitu data penelitian berupa angka dan analisis menggunakan statistik (Sugiyono, 2009).

Sumber data primer diperoleh dengan cara menyebarkan suatu daftar pernyataan (kuesioner) yang cukup terinci dan lengkap tentang objek yang diteliti kepada karyawan PT Setia Makmur Cemerlang (SMC). Kuesioner merupakan seperangkat pertanyaan atau pernyataan tertulis kepada responden untuk dijawab (Sugiyono, 2009). Kuesioner ditujukan kepada karyawan office PT Setia Makmur Cemerlang. Metode ini digunakan untuk mengukur pengaruh dukungan supervisor dan pemberdayaan terhadap organizational citizenship behavior (OCB) karyawan melalui pemberian bobot pada setiap alternatif jawaban yang tersedia berdasarkan skala Likert. Peneliti terjun langsung ke lapangan untuk mengumpulkan data melalui pembagian kuesioner. Responden pada penelitian ini adalah semua karyawan office yang ada di PT Setia Makmur Cemerlang (SMC). Pengambilan sampel dilakukan dalam metode sensus, yaitu dengan mengambil populasi seluruh karyawan PT Setia Makmur Cemerlang. Adapun sumber data sekunder diperoleh berdasarkan penelitian terdahulu yang dilakukan oleh peneliti sebelumnya untuk membangun dasar yang kuat bagi penelitian ini. Selain itu, 
data diperoleh dari perpustakaan serta berbagai literatur dari berbagai sumber informasi baik yang dapat diakses melalui media cetak maupun media elektronik. Data yang terkumpul diuji validitas, reliabilitas, serta uji asumsi klasik untuk kemudian dianalisis lebih lanjut untuk menjawab tujuantujuan penelitian menggunakan analisis regresi linier sederhana dan regresi linier berganda. Menurut Wijaya (2009), regresi linier sederhana digunakan jika variabel dependen dipengaruhi hanya oleh satu variabel independen. Lebih lanjut, regresi linier berganda digunakan untuk menguji pengaruh lebih dari satu independen variabel terhadap dependen (Wijaya, 2009). Pengolahan data dilakukan melalui bantuan komputer dengan aplikasi program SPSS (Statistical Product and Service Solution).

Dilihat dari data lama karyawan bekerja, tujuan perusahaan untuk memaksimalkan tenaga kerja lebih ditingkatkan lagi. Berdasarkan data yang diperoleh, lebih banyak karyawan baru dibandingkan karyawan lama, berarti belum semua karyawan PT Setia Makmur Cemerlang terindikasi memiliki organizational citizenship behavior. Hasil penelitian ini diharapkan dapat memberikan informasi kepada perusahaan mengenai variabel-variabel yang memengaruhi terciptanya organizational citizenship behavior pada karyawan PT Setia Makmur Cemerlang.

\section{HASIL DAN PEMBAHASAN}

\section{Regresi Sederhana}

\section{Analisis Pengaruh Dukungan Supervisor $\left(\mathrm{X}_{1}\right)$ terhadap Organizational Citizenship Behavior (Y)}

Nilai $\mathrm{R}$ dari Tabel 1 menunjukkan bahwa nilai hubungan antara dukungan supervisor $\left(\mathrm{X}_{1}\right)$ terhadap organizational citizenship behavior (Y) adalah positif sebesar 0,487 termasuk dalam kategori cukup kuat. R Square pada tabel Model Summary sebesar 0,237; berarti besar peran atau kontribusi variabel dukungan supervisor $\left(\mathrm{X}_{1}\right)$ mampu menjelaskan variabel organizational citizenship behavior (Y) sebesar $23,7 \%$. Sementara 76,3\% dijelaskan oleh variabel lain yang tidak diteliti pada penelitian ini.

Tabel 1 Kontribusi Variabel Dukungan Supervisor terhadap Organizational Citizenship Behavior

\begin{tabular}{lcrrrrrrr}
\hline Model & $\boldsymbol{R}$ & $\boldsymbol{R}$ & Adjusted & \multirow{2}{*}{$\begin{array}{c}\text { Std. Error } \\
\text { Std }\end{array}$} & & \multicolumn{3}{c}{ Change Statistics } \\
\cline { 6 - 8 } & & Square & $\boldsymbol{R}$ Square & of the Estimate & $\boldsymbol{R}$ Square Change & F Change & df1 \\
\hline 1 & $.487^{\mathrm{a}}$ & .237 & .224 & .19307 & .237 & 18.049 & 1 \\
\hline
\end{tabular}

a. Predictors: (Constant), Dukungan Supervisor

b. Dependent Variable: Organizational Citizenship Behavior

(Sumber: Data kuesioner yang telah diolah, 2014)

Berdasarkan Tabel 2 diperoleh model persamaan regresi $\mathrm{Y}=10,670+0.440 \mathrm{X} 1$. Pertama, konstanta (a), berarti jika semua variabel bebas memiliki nilai nol (0), nilai variabel terikat (organizational citizenship behavior) sebesar 10,670. Kedua, dukungan supervisor $\left(\mathrm{X}_{1}\right)$ terhadap organizational citizenship behavior $(\mathrm{Y})$, nilai koefisien dukungan supervisor $\left(\mathrm{X}_{1}\right)$ sebesar 0,440 . Hal ini mengandung arti bahwa setiap kenaikan dukungan supervisor satu satuan, maka variabel organizational citizenship behavior (Y) akan naik sebesar 0,440 dengan asumsi bahwa variabel bebas yang lain dari model regresi adalah tetap. Ketiga, koefisien variabel dukungan supervisor $\left(\mathrm{X}_{1}\right)$ berpengaruh secara signifikan terhadap organizational citizenship behavior (Y). Hal ini terlihat dari tingkat signifikansi variabel dukungan supervisor $\left(\mathrm{X}_{1}\right)$ sebesar 0.000 yang lebih kecil daripada 0.05 
Tabel 2 Persamaan Regresi Dukungan Supervisor terhadap Organizational Citizenship Behavior (OCB)

\begin{tabular}{|c|c|c|c|c|c|c|}
\hline \multirow[t]{2}{*}{ Model } & & \multicolumn{2}{|c|}{ Unstandardize Coefficients } & \multirow{2}{*}{$\begin{array}{c}\text { Standardized Coefficients } \\
\text { Beta }\end{array}$} & \multirow[b]{2}{*}{$\mathbf{T}$} & \multirow[b]{2}{*}{ Sig. } \\
\hline & & B & Std. Error & & & \\
\hline \multirow[t]{2}{*}{1} & (Constant) & 10.670 & .312 & & 5.360 & .000 \\
\hline & Dukungan Supervisor & .440 & .104 & .487 & 4.248 & .000 \\
\hline
\end{tabular}

a. Dependent Variable: Organizational Citizenship Behavior

(Sumber: Data kuesioner yang telah diolah, 2014)

Dasar Pengambilan Keputusan:

Sig $\geq 0,05$ maka $R_{\sigma}$ diterima;

Sig $<0,05$ maka $\boldsymbol{K}_{0}$ ditolak.

Hipotesis 1:

$H_{0}$ : Tidak ada pengaruh yang signifikan antara dukungan supervisor $\left(\mathrm{X}_{1}\right)$ terhadap organizational citizenship behavior (Y).

$H_{a}$ : Ada pengaruh yang signifikan antara dukungan supervisor $\left(\mathrm{X}_{1}\right)$ terhadap organizational citizenship behavior (Y).

Hasil keputusan mengacu pada hasil nilai Sig $=0,000<0,05$ dengan demikian dapat dikatakan bahwa $\boldsymbol{H}_{0}$ ditolak. Artinya, terdapat pengaruh yang signifikan antara dukungan supervisor $\left(\mathrm{X}_{1}\right)$ terhadap organizational citizenship behavior (Y).

\section{Analisis Pengaruh Pemberdayaan $\left(\mathrm{X}_{2}\right)$ terhadap Organizational Citizenship Behavior (Y)}

Nilai R pada Tabel 3 menunjukkan bahwa nilai hubungan antara pemberdayaan $\left(\mathrm{X}_{2}\right)$ terhadap organizational citizenship behavior (Y) adalah positif sebesar 0,510 termasuk dalam kategori kuat. Nilai R Square pada tabel Model Summary sebesar 0,260; berarti besar peran atau kontribusi variabel pemberdayaan $\left(\mathrm{X}_{2}\right)$ mampu menjelaskan variabel organizational citizenship behavior $(\mathrm{Y})$ sebesar $26 \%$. Sementara $74 \%$ dijelaskan variabel lain yang tidak diteliti pada penelitian ini.

Tabel 3 Kontribusi Variabel Pemberdayaan

terhadap Organizational Citizenship Behavior (OCB)

\begin{tabular}{|c|c|c|c|c|c|c|c|}
\hline \multirow[t]{2}{*}{ Model } & \multirow[t]{2}{*}{$\mathbf{R}$} & \multirow{2}{*}{$\begin{array}{c}R \\
\text { Square }\end{array}$} & \multirow{2}{*}{$\begin{array}{l}\text { Adjusted } \\
\text { R Square }\end{array}$} & \multirow{2}{*}{$\begin{array}{l}\text { Std. Error } \\
\text { of the Estimate }\end{array}$} & \multicolumn{3}{|c|}{ Change Statistics } \\
\hline & & & & & R Square Change & F Change & df1 \\
\hline 1 & $.510^{\mathrm{a}}$ & .260 & .247 & .19018 & .260 & 20.385 & 1 \\
\hline
\end{tabular}

a. Predictors: (Constant), Pemberdayaan

b. Dependent Variable: Organizational Citizenship Behavior

(Sumber: Data kuesioner yang telah diolah, 2014)

Berdasarkan Tabel 4 diperoleh model persamaan regresi $\mathrm{Y}=11,737+0.454 \mathrm{X} 2$. Pertama, konstanta (a), berarti jika semua variabel bebas memiliki nilai nol (0), nilai variabel terikat (organizational citizenship behavior) sebesar 11,737. Kedua, pemberdayaan $\left(\mathrm{X}_{2}\right)$ terhadap organizational citizenship behavior $(\mathrm{Y})$. Nilai koefisien pemberdayaan $\left(\mathrm{X}_{2}\right)$ sebesar 0,454 . Hal ini mengandung arti bahwa setiap kenaikan pemberdayaan satu satuan maka variabel organizational citizenship behavior (Y) akan naik sebesar 0,454 dengan asumsi bahwa variabel bebas yang lain dari model regresi adalah tetap. Ketiga, koefisien variabel pemberdayaan $\left(\mathrm{X}_{2}\right)$ memengaruhi secara signifikan terhadap organizational citizenship behavior (Y). Hal ini terlihat dari tingkat signifikansi variabel pemberdayaan $\left(\mathrm{X}_{2}\right)$ sebesar 0.000 yang lebih kecil daripada 0.05 . 
Tabel 4 Persamaan Regresi Pemberdayaan

terhadap Organizational Citizenship Behavior (OCB)

\begin{tabular}{|c|c|c|c|c|c|c|}
\hline \multirow[t]{2}{*}{ Model } & & \multicolumn{2}{|c|}{ Unstandardized Coefficients } & \multirow{2}{*}{$\begin{array}{c}\text { Standardized Coefficients } \\
\text { Beta }\end{array}$} & \multirow[b]{2}{*}{$\mathbf{t}$} & \multirow[b]{2}{*}{ Sig. } \\
\hline & & B & Std. Error & & & \\
\hline 1 & (Constant) & 11.737 & .278 & & 6.242 & .000 \\
\hline & Pemberdayaan & .454 & .101 & .510 & 4.515 & .000 \\
\hline
\end{tabular}

a. Dependent Variable: Organizational Citizenship Behavior

(Sumber: Data kuesioner yang telah diolah, 2014)

Dasar Pengambilan Keputusan:

Sig $\geq 0,05$ maka $R_{\theta}$ diterima;

Sig $<0,05$ maka $\mathbb{R}_{q}$ ditolak.

Hipotesis 2:

$H_{0}$ : Tidak ada pengaruh yang signifikan antara pemberdayaan $\left(\mathrm{X}_{2}\right)$ terhadap organizational citizenship behavior (Y).

$H_{Q}$ : Ada pengaruh yang signifikan antara pemberdayaan $\left(\mathrm{X}_{2}\right)$ terhadap organizational citizenship behavior (Y).

Hasil keputusan melihat bahwa nilai Sig $=0,000<0,05$ dengan demikian $\boldsymbol{H}_{0}$ ditolak. Artinya terdapat pengaruh yang signifikan antara pemberdayaan $\left(\mathrm{X}_{2}\right)$ terhadap organizational citizenship behavior (Y).

\section{Regresi Berganda}

\section{Analisis Pengaruh Dukungan Supervisor $\left(\mathrm{X}_{1}\right)$ dan Pemberdayaan $\left(\mathrm{X}_{2}\right)$ terhadap Organizational Citizenship Behavior (Y)}

Nilai R Square pada tabel Model Summary (Tabel 5) sebesar 0,285; berarti besar peran atau kontribusi variabel dukungan supervisor $\left(\mathrm{X}_{1}\right)$ dan pemberdayaan $\left(\mathrm{X}_{2}\right)$ mampu mejelaskan variabel organizational citizenship behavior (Y) sebesar 28,5\%. Sementara 71,5\% dijelaskan variabel lain yang tidak diteliti pada penelitian ini. Nilai R menunjukkan korelasi antara variabel dukungan supervisor dan pemberdayaan terhadap organizational citizenship behavior adalah positif sebesar 0,534 termasuk dalam kategori kuat.

Tabel 5 Kontribusi Variabel Dukungan Supervisor dan Pemberdayaan terhadap Organizational Citizenship Behavior (OCB)

\begin{tabular}{llrrr}
\hline Model & $\mathbf{R}$ & $\boldsymbol{R}$ Square & Adjusted $\mathbf{R}$ Square & Std. Errorof the Estimate \\
\hline 1 & $.534^{\mathrm{a}}$. & .285 & .260 & .18862 \\
\hline
\end{tabular}

(Sumber: Data kuesioner yang telah diolah, 2014)

Berdasarkan Tabel 6 diperoleh model persamaan regresi $\mathrm{Y}=7,532+0,216 \mathrm{X} 1+0,294 \mathrm{X} 2$. Pertama, konstanta (a), berarti jika semua variabel bebas memiliki nilai nol (0), nilai variabel terikat (organizational citizenship behavior) sebesar 7,532. Kedua, dukungan supervisor $\left(\mathrm{X}_{1}\right)$ terhadap organizational citizenship behavior $(\mathrm{Y})$. Nilai koefisien dukungan supervisor $\left(\mathrm{X}_{1}\right)$ sebesar 0,216 . Hal ini mengandung arti bahwa setiap kenaikan dukungan supervisor satu satuan maka variabel organizational citizenship behavior (Y) akan naik sebesar 0,216 dengan asumsi bahwa variabel bebas yang lain dari model regresi adalah tetap. Ketiga, dukungan supervisor $\left(\mathrm{X}_{1}\right)$ memiliki nilai signifikansi sebesar 0,017, yang kurang dari 0,05 dan t-Test sebesar 2,401 lebih besar dari t tabel (df $=59, \alpha=$ $0,05)$ adalah 1,671. Hal ini berarti dukungan supervisor $\left(\mathrm{X}_{1}\right)$ memiliki pengaruh yang signifikan 
terhadap organizational citizenship behavior (Y). Keempat, pemberdayaan $\left(\mathrm{X}_{2}\right)$ terhadap organizational citizenship behavior $(\mathrm{Y})$, nilai koefisien pemberdayaan $\left(\mathrm{X}_{2}\right)$ sebesar 0,294 . Hal ini mengandung arti bahwa setiap kenaikan pemberdayaan satu satuan maka variabel organizational citizenship behavior (Y) akan naik sebesar 0,294 dengan asumsi bahwa variabel bebas yang lain dari model regresi adalah tetap. Kelima, pemberdayaan $\left(\mathrm{X}_{2}\right)$ memiliki nilai signifikansi sebesar 0,007 (< $0,05)$ dan t-test sebesar 2,943 yang lebih besar dari $\mathrm{t}$ tabel $(\mathrm{df}=59, \alpha=0,05)$ yaitu 1,671 . Artinya, pemberdayaan $\left(\mathrm{X}_{2}\right)$ memiliki pengaruh yang signifikan terhadap organizational citizenship behavior (Y). Keenam, berdasarkan penjelasan, dapat disimpulkan bahwa pemberdayaan $\left(\mathrm{X}_{2}\right)$ memiliki tingkat signifikansi terbesar atau memiliki efek signifikan terhadap organizational citizenship behavior (Y).

Tabel 6 Persamaan Regresi Dukungan Supervisor dan Pemberdayaan terhadap Organizational Citizenship Behavior (OCB)

\begin{tabular}{llrrrrr}
\hline Model & & \multicolumn{2}{c}{ Unstandardized Coefficients } & Standardized Coefficients & & S \\
\cline { 3 - 6 } & & B & Std. Error & Beta & & Sig. \\
\hline 1 & (Constant) & 7.532 & .312 & & 5.904 & .000 \\
& Dukungan Supervisor & .216 & .154 & .238 & 2.401 & .017 \\
& Pemberdayaan & .294 & .152 & .331 & 2.943 & .007 \\
\hline
\end{tabular}

a. Dependent Variable: Organizational Citizenship Behavior

(Sumber: Data kuesioner yang telah diolah, 2014)

Dasar Pengambilan Keputusan :

Sig $\geq 0,05$ maka $R_{\odot}$ diterima;

Sig $<0,05$ maka $R_{Q}$ ditolak.

Hipotesis 3:

$E_{\bullet}$ : Tidak ada pengaruh yang signifikan antara dukungan supervisor $\left(\mathrm{X}_{1}\right)$ dan pemberdayaan $\left(\mathrm{X}_{2}\right)$ terhadap organizational citizenship behavior (Y).

$H_{a}$ : Ada pengaruh yang signifikan antara dukungan supervisor $\left(\mathrm{X}_{1}\right)$ dan pemberdayaan $\left(\mathrm{X}_{2}\right)$ terhadap organizational citizenship behavior (Y).

Dengan demikian, hasil keputusan berdasarkan hasil nilai $\operatorname{Sig}=0,017<0,05$ yang telah dijelaskan dapat dikatakan bahwa $\boldsymbol{H}_{0}$ (dukungan supervisor) ditolak; demikian pula dengan nilai $\mathrm{Sig}=$ $0,007<0,05$. Maka dapat disimpulkan bahwa $\boldsymbol{H}_{0}$ (pemberdayaan) juga ditolak. Artinya pernyataan tersebut adalah bahwa terdapat pengaruh yang signifikan antara dukungan supervisor $\left(\mathrm{X}_{1)}\right.$ dan pemberdayaan $\left(\mathrm{X}_{2}\right)$ terhadap organizational citizenship behavior $(\mathrm{Y})$.

Hasil analisis dapat dilihat dalam bagan sebagai berikut.

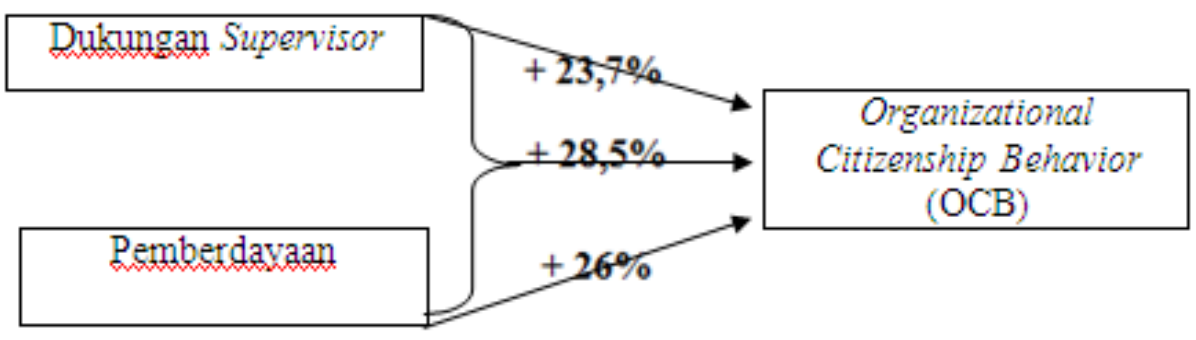

Gambar 1 Bagan Hasil Penelitian 


\section{SIMPULAN}

Hasil penelitian membuktikan bahwa semua variabel independen, yaitu dukungan supervisor dan pemberdayaan mempunyai pengaruh yang signifikan terhadap organizational citizenship behavior sebagai variabel dependen. Secara parsial, dukungan supervisor berpengaruh signifikan terhadap organizational citizenship behavior. Demikian pula dengan pemberdayaan yang juga berpengaruh signifikan terhadap organizational citizenship behavior. Adapun secara simultan dapat disimpulkan bahwa dukungan supervisor dan pemberdayaan berpengaruh signifikan terhadap organizational citizenship behavior.

\section{Saran}

Mengacu pada simpulan, beberapa rekomendasi yang dapat diberikan pada PT Setia Makmur Cemerlang adalah sebagai berikut. Pertama, dengan adanya pengaruh dukungan supervisor terhadap organizational citizenship behavior, maka sebaiknya perusahaan tidak hanya mengawasi karyawan dalam bekerja, akan tetapi juga membimbing mereka dalam melakukan pekerjaan. Perusahaan harus bersikap lebih terbuka pada karyawan dalam hal pekerjaan. Misalnya, supervisor sebaiknya lebih komunikatif dan terbuka pada bawahannya, terutama jika ada kebijakan baru, perkembangan situasi, maupun masalah yang dihadapi perusahaan kepada karyawan. Dengan dukungan supervisor yang tepat, besar kemungkinan karyawan mengindikasikan terciptanya OCB pada diri mereka. Kedua, mengingat bahwa pemberdayaan juga berpengaruh terhadap organizational citizenship behavior, perusahaan sebaiknya memberikan tugas yang jelas kepada karyawan, menghargai pekerjaan yang diselesaikan karyawan, mengikutsertakan karyawan dalam pembuatan kebijakan perusahaan, memberikan informasi yang jelas yang dibutuhkan oleh perusahaan, memberikan waktu yang cukup kepada karyawan untuk menyelesaikan pekerjaan, dan memberikan perlengkapan kerja yang mencukupi untuk menyelesaikan pekerjaan. Dengan demikian, implementasi pemberdayaan dengan baik akan menciptakan karyawan terindikasi OCB pada diri mereka. Ketiga, adapun secara simultan hasil penelitian menunjukkan adanya dukungan supervisor dan pemberdayaan yang berpengaruh terhadap organizational citizenship behavior. Oleh karena itu, PT Setia Makmur Cemerlang sebaiknya mengarahkan karyawan untuk menciptakan organizational citizenship behavior pada diri mereka. Dengan implementasi dukungan supervisor dan pemberdayaan dengan baik, OCB pada diri karyawan akan tercipta. Makin banyak karyawan yang terindikasi OCB pada diri mereka, maka hal tersebut akan memengaruhi kinerja tim yang pada akhirnya memengaruhi kinerja perusahaan.

\section{DAFTAR PUSTAKA}

Jin-Liang, W., \& Hai-Zhen, W. (2012). The influences of psychological empowerment on work attitude and behavior in Chinese organizations. Journal of Business Management, 6(30), 89388947. http://www.academicjournals.org/article/article1380711057_Jin-Liang\%20and\%20HaiZhen.pdf

Sekaran, U. \& Roger. (2010). Research Methods for Business ( $5^{\text {th }}$ Edition). UK: John Wiley.

Sugiyono. (2009). Metode Penelitian Bisnis. Bandung: Alfabeta.

Wijaya, T. (2009). Analisis Data Penelitian. Yogyakarta: Universitas Atma Jaya Yogyakarta.

Zaigham, N. (2010). Impact of supportive supervisors and empowerment on organizational citizenship behavior (OCB) in the private sector of Pakistan. New Horizons, 4(2), 32-44. 